\title{
FRACTURED CONSENSUS Islamic Groups and the Perceived Military Politics in Post-Suharto Indonesia
}

\author{
Lukman Hakim \\ IAIN Sunan Ampel Surabaya, Indonesia
}

Book Review

\begin{tabular}{|c|c|c|}
\hline & Book title & $\begin{array}{l}\text { Military Politics, Islam, and the State in } \\
\text { Indonesia }\end{array}$ \\
\hline $\begin{array}{l}\text { Islam, and the } \\
\text { State in Indonesia }\end{array}$ & Author & : Marcus Mietzner \\
\hline 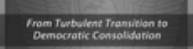 & No. of Pages & : $\quad x v i+426$ \\
\hline & Year & : 2009 \\
\hline & Publisher & $\begin{array}{l}\text { Institute of Southeast Asian Studies, } \\
\text { Singapore }\end{array}$ \\
\hline
\end{tabular}

This book deals with the position of the military, both individually and institutionally, in the democratisation process in post-Suharto Indonesia. It is particularly concerned with problems resulting from civil-military relations. In Indonesia, as in any developing country, the transition from an authoritarian to a democratic system faced problems. On the one hand, military engagement in political affairs had to be reduced; on the other hand, democratisation required military involvement in order to preserve Indonesia's territory and national integrity.

An important factor in the transition to democracy is the ability to control the role of military institutions in political affairs. Eastern European countries have had considerable success in controlling the domination of the military, on the one hand, and restrengthening legitimate democratically-elected civilian government, on the other. According to Samuel Huntington, establishing professional military is a 
requirement for some donor countries to support military assistance to countries that are in transition (p.15).

Unlike other research into the Indonesian armed forces which have focused more on internal views, Mietzner's book emphasizes the military-civil relations and the contribution of conflicts among civilians and Muslim groups in determining military involvement in political affairs following the collapse of Suharto's New Order regime in 1998.

To describe the involvement of the Indonesian military in political affairs, Mietzner approaches the subject chronologically, from Indonesia's Liberal Era, beginning in 1945, through to 2008, one decade after New Order regime collapsed.

The book encompasses eight main parts. The first part (19451997) lays out the historical legacy of the active role of the military in Indonesia's independence process and interprets Nasution's concept of the Middle Way. It examines the legitimacy of the military's involvement in Indonesian politics, known as dual-function concept of the Armed Forces. This historical experience was used by the Indonesian military to justify the special civil-military relations in Indonesia, compared to other countries.

In this part, Mietzner also describes the relationship between Islam and the state. In Indonesia, the country with the largest Muslim population in the world, the position of Islam in determining the development of the country's political system has been highly significant. There are two main arguments in this matter, the first relates to the formal role of Islam in the state, and second concerns the role of the state as the main distributor of funds, positions, and the rights of particular constituencies.

In the political sphere, Fealy notes that Islamic schools have major differences in ideology, policy and leadership style. Each school uses different aspects of Islamic thought and different traditions to legitimize its own distinctive approach to politics. In general, most controversy revolves around issues of structure, identity, and state resources. Disputes between modernist and traditionalist groups, which soldiers had often used to mediate and take advantage of, happened again in the post-Suharto era. In addition, conflicts between Indonesian Muslim organisations, particularly modernists and traditionalists during the Old and New Order, as well as military interventions, were fundamental reasons for civilians to establish a strong state. 
Part two of this book specifically discusses about the political crisis and regime change of1997-1998. In this chapter, Mietzner describes the conflict within the armed forces and the implications for regime change in Indonesia, as well as changes in civil-military relations in the early reform era. In addition, Nahdlatul Ulama (NU) and Muhammadiyah, as the two largest Muslim organizations, are given a special place. NU is considered an important player in determining the fate of Suharto in the critical economic and political situation. These organizations also helped to preserve and perpetuate the authoritarian regime 1965. In the New Order era, NU chose to cuddle up to Suharto for three reasons, namely political strategy, personal ambition, and the economic and social interests of the Nahdliyyin. However, bearing earth mass relationship is not always in line with the five-star general.

The same thing applied to Muhammadiyah. This organization experienced a fluctuating relationship with Suharto and at the same time with the military. When Suharto lost control of the situation in 1998, his ally Wiranto tried to convince people to calm down and provide the opportunity for government to overcome the economic crisis. Meanwhile, his colleague, Agum Gumelar, tried to establish communications with the so-called "reformers" to open a dialogue with the "dissidents". However, this attempt failed, and Suharto was toppled.

Part three of this book depicts the post-authoritarian transition (1998-2004). The author of this book analyzes the conflict between the two largest Muslim groups in Indonesia, NU and Muhammadiyah. He argues that their sharp conflict in 1998-2004 provided an opportunity for the military to develop their involvement in the politics and protect the interests of the military institution. Conversely, the relatively stable condition of civil society after 2004 appeared to marginalize the military from the centre of power. The post-2004 civil-military relations are explained in a broader fashion in the last chapter. Mietzner states that the future role of Indonesian military in politics is highly dependent on the ability of civilian leaders to manage democratic institutions and carry out procedures correctly.

Where many books pay little attention to the role of Muslim groups, this book provides a sound analysis of the significant role of these groups in mobilizing many internal and civil conflicts. These conflicts contributed to the return of the military in post-Suharto politics. A result of field research conducted in the crucial period from 
the final days of the New Order regime through nearly two decades of the reform era, his book constitutes a detailed analysis of the historical development of civil-military relations. Moreover, the interpretation of research data regarding military involvement in politics and civilmilitary relations from the independence period until 2008 is very critical. Consequently, this book contributes significantly to the history of the military's struggle in politics. Moreover, it presents a critical account of civilian-political behaviour that was less constructive towards democratic consolidation.

Overall, Military Politics, Islam and the State in Indonesia provides a different perspective from other books, especially concerning the repositioning of the Indonesian military in the transition period. It also lays out some basic measures that must be taken by Indonesian civilians, against the background of the military's influence in politics, to build a "strong country" in the era of democratic transition.] 